\title{
Associations Between Housing, Management, and Morbidity During Rearing and Subsequent First-Lactation Milk Production of Dairy Cows in Southwest Sweden
}

\author{
C. Svensson ${ }^{1}$ and J. Hultgren \\ Department of Animal Environment and Health, Swedish University of Agricultural Sciences, PO Box 234, SE-532 23 Skara, Sweden
}

\begin{abstract}
Information regarding health, management, and housing from birth to first calving was collected for 1,029 Swedish Reds, 991 Swedish Holsteins, and 40 heifers of crossbreed or other breeds on bimonthly farm visits made by 3 project veterinarians to 107 dairy herds in southwest Sweden. Additional data were obtained from the official milk- and health-recording program. Milk production at first test day after calving [energycorrected milk (ECM)1] and during the first $305 \mathrm{~d}$ of lactation (ECM305), respectively, were analyzed by 2level (animal; herd) linear regression, after initial screening by univariable analyses of 67 potentially important predictors. The ECM1 ranged from 7.9 to 48.0 (median $=27.1) \mathrm{kg}$, and ECM305 ranged from 3,764 to $12,136$ (median $=8,006) \mathrm{kg}$. In the final models, factors associated with ECM1 or ECM305 or both were age at first calving, body condition score at first service, breed, calfhood diarrhea, calving season, composite somatic cell count at first test day, daily weight gain from weaning to first service, housing system after calving, and increase in concentrate fed around calving. Higher age at calving was associated with higher production. Production also increased with higher daily weight gains from weaning to first service. Swedish Holsteins produced more than Swedish Reds, cows calving in May to September produced more than those calving during other months, and cows housed in short stalls after calving produced more than those in cubicles. Body condition scores $\geq 3.2$ at first service were associated with lower ECM305 than scores $\leq 2.9$. Animals that contracted mild diarrhea during their first 3 mo of life had lower ECM305 than animals without diarrhea, whereas animals receiving a high increase in concentrate pre- and postcalving had higher ECM305 than those subjected to a more moderate increase. Cows with a composite somatic cell count $>1$ million cells/milliliter
\end{abstract}

Received March 27, 2007.

Accepted December 14, 2007.

${ }^{1}$ Corresponding author: Catarina.Svensson@hmh.slu.se at first test day produced less milk on the same day than cows with lower counts. It was concluded that rearing factors and calfhood health status can influence first lactation milk production.

Key words: dairy cattle, management, morbidity, milk production

\section{INTRODUCTION}

Inheritance and the feeding and management of the lactating cow influence its milk production. Many farmers also associate a high milk yield with a successful rearing of the replacement heifer. First-lactation milk production is affected by BW at calving (Carson et al., 2002); Keown and Everett (1986) reported optimal milk production for Holstein cows with a BW of between 544 and $567 \mathrm{~kg}$ at first calving. Milk production is also affected by age at calving (Moore et al., 1991). Furthermore, in several studies, high feeding regimes and hence high daily weight gains after sexual maturity and during pregnancy have resulted in higher BW at calving and increased milk production (e.g., Foldager and Sejrsen, 1991). At an early calving, accelerated postpubertal growth was, however, found to be associated with lower first-lactation milk production (Hoffman et al., 1996), and no effect on mammary development and milk yield was reported by Sejrsen et al. (1982). There is substantial evidence of a negative effect of high weight gains during the period of allometric mammary growth (i.e., from approximately 90 to 300 $\mathrm{kg}$ of BW; Sejrsen et al., 1982). Contradicting results have, however, been reported (Gardner et al., 1988; Pirlo et al., 1997) and might be due to different feed intensity, protein levels, period of study, and age at calving. Further studies and different types of data are needed to elucidate the complexity of these matters.

Beside experiments on BW and weight gain, there are few reports on the effect of management and housing of the dairy calf and replacement heifer on subsequent milk production. Reports on effects of morbidity during the rearing period are especially scarce. Diseases early in life have been associated with increased risks for 
morbidity later during the rearing period (Svensson et al., 2006a), and long-term effects of calf morbidity on survival and age at calving have been reported (Warnick et al., 1994; van der Fels-Klerx et al., 2002). CoboAbreu et al. (1979), studying animals from 1 university dairy herd in Ontario, found (although not significant) that cows experiencing respiratory disease as calves, or in adult life, had a poorer milk production. However, when Britney et al. (1984) later studied data from the same university herd plus 1 additional institutional farm, they did not detect any effect on milk production of 5 types of calf morbidity. They therefore suggested that the poor milk production reported by Cobo-Abreu et al. (1979) was mainly associated with respiratory disease postcalving and not with calfhood pneumonia. Results from institutional herds might not be applicable to commercial herds because of differences in management, veterinary service, and economic decision-making. Warnick et al. (1995) therefore instead studied commercial dairy farms but also failed to detect an association between calf morbidity and subsequent firstlactation (305 d) and second test day milk production. Data comprised just 728 heifers from 25 herds and were based on owner-diagnosed calf diseases. Svensson et al. (2003) reported that only half the cases of pneumonia diagnosed by a project veterinarian at bimonthly visits were recognized by farmers. Hence, diagnoses by owners are likely to underestimate the true disease occurrence and thus potentially bias the results. The aim of the present study was to investigate the associations of housing, management, and farmer- and veterinarydiagnosed morbidity of dairy calves and replacement heifers on their subsequent first-lactation milk production using epidemiological data from dairy herds in southwest Sweden.

\section{MATERIALS AND METHODS}

As previously described by Lundborg et al. (2003), 122 dairy farms with 28 to 94 cows in the county of Skaraborg in the southwest of Sweden enrolled in the official milk-recording program were selected on basis of their housing system for calves and replacement heifers. In 1998, herd sizes in the range of 28 to 94 cows represented $56 \%$ of all Swedish dairy herds. In the selected farms, all heifer calves born in $1998(\mathrm{n}=3,081)$ were monitored by research staff from birth to first calving or, alternatively, to the day of their removal from the study. In total, 179 (5.8\%) of the animals died, 267 (8.7\%) were slaughtered, 259 (8.4\%) were sold before calving, and $250(8.1 \%)$ were lost because the farmer could no longer participate or because the farm left the official milk-recording program. Fifty-eight cows (1.9\%) lacked production data, and 8 cows $(0.3 \%)$ were excluded due to abortions. All of the remaining 2,060 animals from 107 herds were included in the present study. They were Swedish Reds $(\mathrm{n}=1,029)$, Swedish Holsteins $(\mathrm{n}=999)$, and crossbreeds or animals of other breeds $(n=40)$. As previously reported by Svensson et al. (2006b), the 107 herds were larger (median $=50.6$ vs. 41.7 cows; $95 \%$ confidence interval for the difference between means: 3.7 to 9.5 cows) and had a higher average annual herd-level milk production (median $=9,127$ vs. $8,843 \mathrm{~kg} ; 95 \%$ confidence interval for difference between means: 153 to $615 \mathrm{~kg}$ ) than the sampling frame consisting of all herds with 28 to 94 cows included in the Swedish official milk- and healthrecording program from September to August 2001 when most of the animals calved $(n=5,132)$.

Calves were kept in single pens, or in group pens bedded with straw or sawdust until weaning, and then in group pens with slatted floors, deep litter, or in deepbedded pack pens. However, especially heifers on slats were subsequently transferred to similar housing systems as for lactating cows in the herds, mainly tie stalls. From $210 \mathrm{~d}$ of age to breeding, approximately $8 \%$ of the heifers were tethered. From breeding to calving, 4\% were kept in cubicles and $45 \%$ in other systems, mainly tethered. Grazing was generally practiced between May and October. However, 9\% of the heifers were not grazed before calving.

\section{Data Collection}

Diseases prepartum were recorded by farmers and by project veterinary surgeons visiting the farms bimonthly to make a brief physical examination of the calves. The project veterinarians recorded information about building type, housing system, stocking rate, and age distribution. They collected information about the indoor feed rations offered and weighed the amounts of feed ingredients given daily to calves and heifers within specific age groups (Hessle et al., 2004). Project veterinarians also measured the $\mathrm{NH}_{3}$ concentration, temperature, and relative humidity of the air in the buildings where the calves and replacement heifers were housed throughout the rearing period, as previously described by Svensson et al. (2006a).

For each calf, the farmers were requested to record the breed, the place and time of birth, whether the calving had been supervised, the time from birth to first observed ingestion of colostrum, the main method of feeding the first 2 meals of colostrum to the calf, and the main source of the first 2 meals of colostrum fed to the calf. The farmers were also requested to measure the heart girth of the animals at birth, at weaning, at first service, at turn-outs to pasture and housings in their first and second grazing periods (or if not grazed 
during corresponding autumns), and at calving. The heart girths were transformed to live weights, and daily weight gains were calculated individually for the periods from birth to weaning, from weaning to 6 to 9 mo of age, from 6 to 9 mo of age to first service, from first service to calving, and from birth to calving, as previously described by Hessle et al. (2004). Body condition was scored by AI technicians or the project veterinary surgeons at first insemination using the method described by Edmonson et al. (1989).

Information on monthly milk production and cow composite SCC was obtained from the official milk-recording program. This program includes $86 \%$ of all dairy herds in Sweden and is based on results from test milkings reported monthly by farmers. Milk production from the day after first calving until $305 \mathrm{~d}$ of lactation or culling (305-d milk production) was calculated assuming recorded test day yields at each day from halfway from the preceding test day to halfway to the following.

\section{Data Edits and Statistical Analyses}

Data were edited and descriptive statistics created in Microsoft Office Excel 2003 spreadsheet software (Microsoft Corp., Redmond, WA) and JMP Statistical Discovery software, release 6 (SAS Institute Inc., Cary, NC). Two continuous outcome traits expressed in kilograms of ECM were modeled: milk yield at first test day before $81 \mathrm{~d}$ in milk (ECM1) and 305-d milk production (ECM305). Associations between each trait and the morbidity of the animals and their housing, feeding, and management before calving were investigated by a linear mixed model using the MIXED procedure in SAS for Windows software package, version 9 (SAS Institute Inc.), assuming normality of residuals. The models were defined by the equation:

$$
Y_{i j}=\beta_{0}+u_{0 j}+\Sigma\left(\beta_{\mathrm{m}}+u_{\mathrm{m}}\right) X_{\mathrm{m} i j}+e_{i j}
$$

where $Y_{i j}=$ the milk production of cow $i$ in herd $j ; \beta_{0}=$ the intercept; $u_{0 j}=$ a random intercept effect at the herd level; $\beta_{\mathrm{m}}=$ regression coefficients expressing included fixed effects; $u_{\mathrm{m}}=$ parameters expressing included random slope effects at the herd level; $X_{\mathrm{m} i j}=$ covariates; and $e_{i j}=$ a random term at the cow level.

A total of 67 independent cow- and herd-level variables, representing housing, management, feeding, growth, body condition, and health during rearing were considered in the models. Of these variables, 12 were justified by hypotheses, and the remaining were possible confounders. Initially, calving weight was not considered as a predictor. Continuous variables were categorized; when biologically relevant categories were lacking, quartiles were used as cut-off points. For logical reasons, the set of predictors considered varied between outcome traits. Univariable analyses were performed, testing (one at a time) the predictors possibly associated with each trait (with a random intercept effect of herd in model) and selecting those significant at type $3 P_{F} \leq 0.30$, where $P_{F}=$ significance level based on $F$-test. Based on previous knowledge and results from the described initial selection, confounding variables representing breed, calving year, calving season, and housing system after calving (for categories see Table 1) were forced into all models henceforth. Including the random intercept effect of herd, remaining selected independent variables were tested once again (one at a time), this time retaining for further analyses only those significant at $P_{F} \leq 0.20$, denoting them eligible predictors.

Eligible predictors (of one or both traits; categories given in Tables 1 or 2 or within brackets) were age at calving, amount of concentrate fed at calving, amount of concentrate fed 2 mo before calving, birth place (maternity pen, tie stall, other place), BCS at first service, calving weight ( $<486 \mathrm{~kg}, 486$ to $522 \mathrm{~kg}, 523$ to $559 \mathrm{~kg}$, $\geq 560 \mathrm{~kg}$ ), daily weight gain from weaning to first service, diarrhea before $91 \mathrm{~d}$ of age, housing from birth to $90 \mathrm{~d}$ of age (6 to 30 animals on automatic milk feeding; 3 to 8 calves on manual milk feeding), housing from birth to first service [single pen to $90 \mathrm{~d}$ and group pen with slatted floor from $91 \mathrm{~d}$; group pen to $90 \mathrm{~d}$ and group pen with slatted floor from $91 \mathrm{~d}$; litter pen or cubicles from 91 to $210 \mathrm{~d}$ and litter pen, cubicles, or tied from $211 \mathrm{~d}$, other, or combinations (mainly changing from litter pen to slats or vice versa)], increase in concentrate fed around calving, number of cows in herd in $1998(<43,43$ to 52,53 to $66, \geq 66)$, other disease before $91 \mathrm{~d}$ of age, and respiratory disease before $91 \mathrm{~d}$ of age (no, mild, severe).

In alternative analyses, calving weight was allowed to enter the models. For both production traits, this resulted in a distinct reduction of the parameter estimates of other predictors, especially those representing different aspects of growth (age at calving, BCS at first service, and daily weight gain from weaning to first service), whereas calving weight itself resulted highly significant. Hence, calving weight was considered an intervening variable (Dohoo et al., 2003), and the alternative models were therefore discarded.

To utilize as many observations as possible, missing values of continuous cow-level predictors were imputed as the mean value in that particular herd. Thus, 550 records received imputed values of calving weight, 443 records of daily weight gain from weaning to first service, and 95 records of daily weight gain until weaning. In the analysis of ECM1, 2,059 observations from 107 
Table 1. Description of included variables and results of final multivariable model of milk yield at first test milking (mean $21 \mathrm{~d}$ ) after calving (kg of ECM) in 2,059 Swedish dairy cows born during 1998 in 107 herds

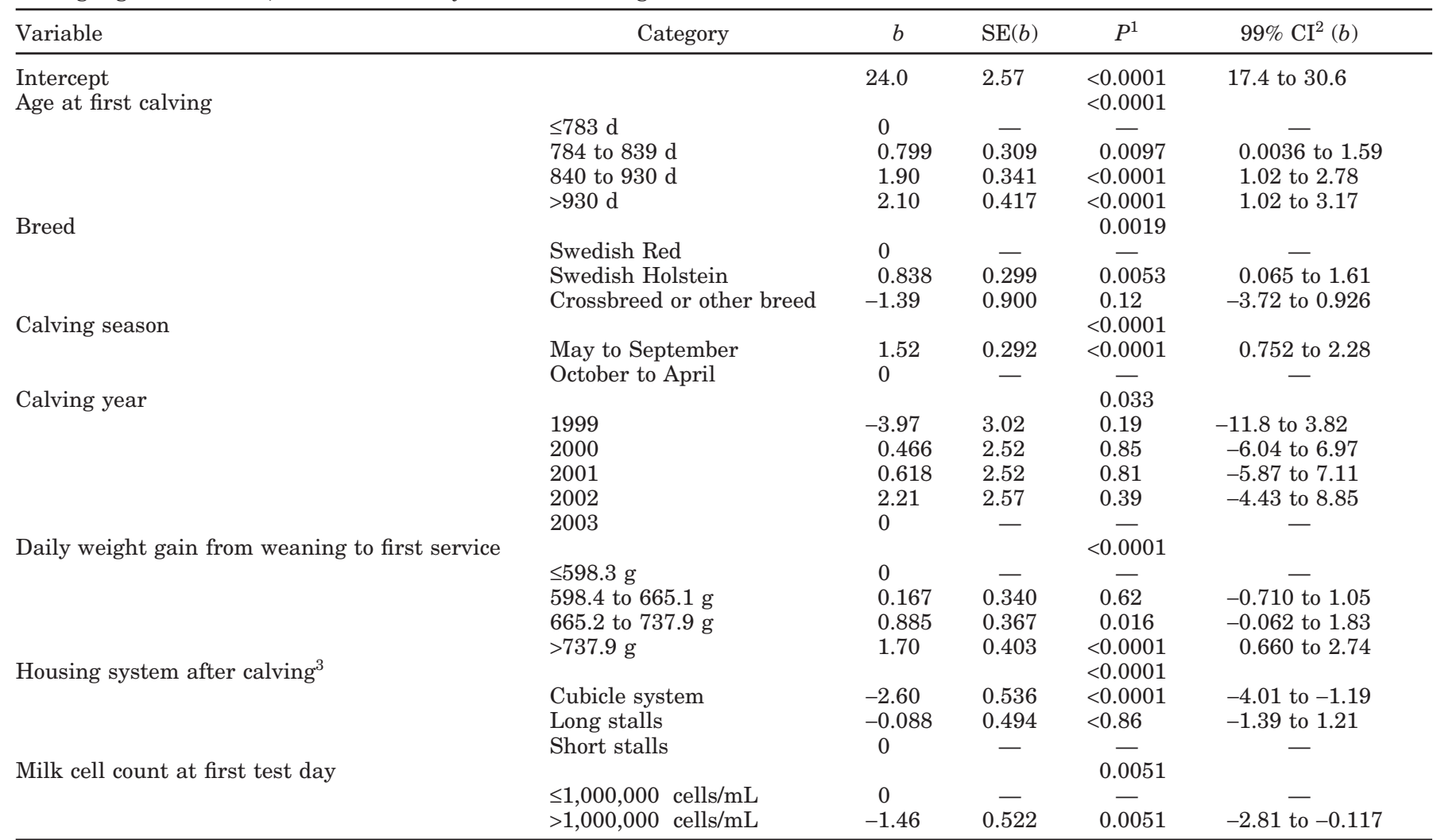

${ }^{1}$ For effects, Wald test; for comparisons of categories, $\chi^{2}$ test $(1 \mathrm{df})$.

${ }^{2} \mathrm{CI}=$ confidence interval.

${ }^{3}$ Cubicle system $=$ loose-housing system with concrete (scraped solid surface or slats) alleys and freestalls for lying; long stalls = housing system for tied cattle equipped with lockable feeding barriers with stalls long enough to allow for rising and lying down behaviors when feeding barriers are closed and cows do not have access to the feeding tables; short stalls = housing system for tied cattle, in which cows have unlimited access to the feeding table and space above feeding table is needed for unrestricted rising and lying down behaviors.

herds were included. The analysis of ECM305 used 1,562 observations from 105 herds. Of the excluded records, the majority lacked production data from 1 or more test milkings.

To check for multicollinearity, each eligible predictor was regressed on all the other eligible predictors together. Unless substantially correlated $(\mathrm{R}>0.5)$, predictors were subjected to further multivariable analysis. The final models were built by a manual stepwise procedure, in each step excluding the least or including the most statistically significant eligible predictor as a fixed effect. All eligible predictors were put into the models from the start, and each set was reduced successively. The model-building continued until all fixed effects were significant at $P_{F} \leq 0.01$ in the type 3 test. The $\alpha$ level was chosen to keep the models reasonably parsimonious and prevent falsely significant associations due to the large number of tests. Thereafter, all first-order interactions were tested through similar backward elimination and retained when $P_{F} \leq 0.01$. No significant interactions were found. Random intercept and random slope terms at the herd level for all fixed effects in the model were tested for inclusion, retaining those significant in a likelihood ratio test at $P \leq 0.05$. Finally, additional adjustments were considered by testing each eligible predictor as a fixed effect once again.

The proportion of outcome variation residing at the herd level (variance partition coefficient) was calculated from simple variance component models (with random intercept herd as the only effect included). The overall model fit was assessed by examining residuals graphically and by the Shapiro-Wilk W test, looking for outliers and checking for homoscedasticity and normality.

\section{RESULTS}

The ECM1 ranged from 7.9 to 48.0 [median = 27.1; interquartile range $(\mathbf{I Q R})=23.6$ to 30.5$] \mathrm{kg}$, and ECM305 ranged from 3,764 to 12,136 (median = 8,006; 
Table 2. Description of included variables and results of final multivariable model of 305-d milk yield (kg of ECM) in 1,562 Swedish dairy cows born during 1998 in 105 herds

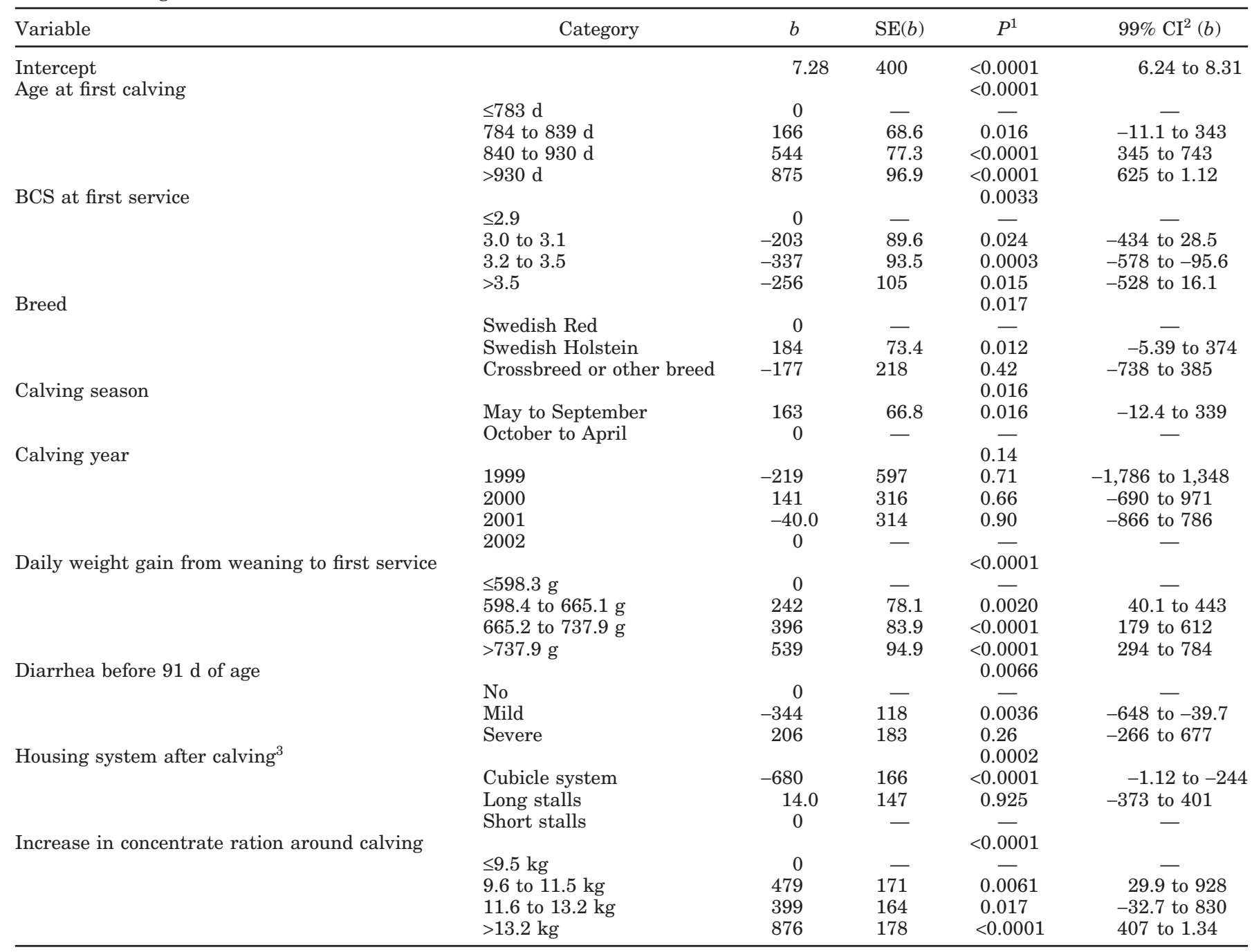

${ }^{1}$ For effects, Wald test; for comparisons of categories, $\chi^{2}$ test $(1 \mathrm{df})$.

${ }^{2} \mathrm{CI}=$ confidence interval.

${ }^{3}$ Cubicle system $=$ loose-housing system with concrete (scraped solid surface or slats) alleys and freestalls for lying; long stalls = housing system for tied cattle equipped with lockable feeding barriers with stalls long enough to allow for rising and lying down behaviors when feeding barriers are closed and cows do not have access to the feeding tables; short stalls = housing system for tied cattle, in which cows have unlimited access to the feeding table and space above feeding table is needed for unrestricted rising and lying down behaviors.

$\mathrm{IQR}=7,187$ to 8,829$) \mathrm{kg}$. Of the total variation in ECM1 and ECM305, 18 and 38\%, respectively, resided at the herd level, and the remaining variation was at the cow level.

The final model of ECM1 is shown in Table 1. Higher ages at calving resulted in successively higher production; calving at $>930 \mathrm{~d}$ gave $2.1 \mathrm{~kg}$ higher ECM1 than calving at $\leq 783 \mathrm{~d}$. Swedish Holsteins had $0.8 \mathrm{~kg}$ higher ECM1 than Swedish Reds, and calving in May to September resulted in a $1.5 \mathrm{~kg}$ higher production than calving during remaining months. Differences between calving years were nonsignificant. Production increased successively with higher daily weight gains from weaning to first service; at $>738 \mathrm{~g}$, cows had $1.7 \mathrm{~kg}$ higher ECM1 than at $\leq 598 \mathrm{~g}$. Cows housed in short stalls had $2.6 \mathrm{~kg}$ higher ECM1 than those in cubicles. No significant difference between short stalls and long stalls was found. A SCC $>1$ million cells per milliliter at first test day was associated with $1.5 \mathrm{~kg}$ less milk on the same day.

All predictors significantly associated with ECM1, except SCC, were also associated with ECM305. In addition, ECM305 was associated with BCS at first service, diarrhea before $91 \mathrm{~d}$ of age, and increase in concen- 
trate feeding around calving (Table 2). Cows calving at $>930 \mathrm{~d}$ produced $975 \mathrm{~kg}$ more than those calving at $\leq 783 \mathrm{~d}$, and cows with a BCS $\geq 3.2$ at first service produced 256 to $337 \mathrm{~kg}$ less than those with a score $\leq 2.9$. The differences in ECM305 between the 2 main breeds and the 2 main calving seasons were 184 and $166 \mathrm{~kg}$, respectively. High-gaining animals (>738 g/d) had a 539 $\mathrm{kg}$ higher ECM305 than those gaining the least. Cows that had contracted mild diarrhea during their first 3 mo of life had $344 \mathrm{~kg}$ lower ECM305 than those without diarrhea. The difference in milk production between cows housed in short stalls and those housed in cubicles was $680 \mathrm{~kg}$, the latter producing less. A large increase in concentrate fed around calving ( 2 mo precalving to maximum level postcalving) was associated with a high production (at $>13.2 \mathrm{~kg}$ increase, $876 \mathrm{~kg}$ higher ECM305 than at $\leq 9.5 \mathrm{~kg}$ increase).

In addition to these variables, housing in single pens until $90 \mathrm{~d}$ of age and litter pens from $90 \mathrm{~d}$ to conception was associated with a higher production $(+3.49 \mathrm{~kg}$ of ECM1, +1,011 kg of ECM305) compared with housing in single pens until $90 \mathrm{~d}$ and slatted pens from $90 \mathrm{~d}$ to conception $(0.05 \geq P>0.01)$ in the univariable analyses with calving year, calving season, housing, breed, and a random effect of herd forced into the model.

\section{DISCUSSION}

In agreement with Hoffman et al. (1996) and Mäntysaari et al. (2002), we found increasing production with increasing age at calving, which is presumably due to a lower energy requirement for growth in older animals. Calving at 32 compared with $\leq 26$ mo of age resulted in nearly $1,000 \mathrm{~kg}$ more milk during the first lactation. However, a high calving age is also known to be associated with a shorter productive life and lower total lifetime milk yield (Lin et al., 1988; Nilsforooshan and Edriss, 2004). Furthermore, it means that more heifers need to be raised on the farm and that the total feed cost per heifer is higher (Tozer and Heinrichs, 2001). Dairy producers have therefore for long been recommended to breed their heifers for early calving in spite of its negative effects on first-lactation milk production. The association of calving age with lifetime milk yield in the currently studied animals remains to be elucidated. A higher production in Holsteins compared with Reds or Ayrshires, as reported here, is well established from previous studies (Danell, 1982; Moore et al., 1991; Mäntysaari et al., 2002).

In the present study, heifers overconditioned at first insemination had lower milk production, but increasing daily weight gains from weaning to first insemination was associated with successively higher milk production. The latter contrasts to results by Foldager and
Sejrsen (1991), who reported that high prepubertal weight gain was associated with decreased first-lactation milk production, presumably related to impaired mammary development (Sejrsen et al., 1982). A negative correlation between BCS at breeding and milk yield was previously reported by Silva et al. (2002). They suggested, in fact, that increased body fatness is a better predictor of impaired mammary development than prepubertal growth rate. When analyzing effects of weight gains within dietary treatment, they found that heifers that grew faster did not have impaired mammary development, and the authors therefore claimed that the high growth rate per se is not the cause of poor udder development in high-gaining animals.

Beside differences in feeding levels, different study periods could explain the conflicting results regarding the effect of high weight gains in the literature. The most critical period for nutritional influence on mammary gland growth is likely to be before puberty, at 3 to 9 mo of age (Waldo et al., 1989). In the present material, start of puberty was not recorded, and heifers were not systematically weighed at 9 mo of age, but BW was extrapolated from heart girth at turn-outs to and housings from pasture (or, if not grazed, at corresponding time points) and at insemination. The median age and BW at first insemination was 531 (IQR $=488$ to 605 ) $\mathrm{d}$ and 387 (IQR $=357$ to 430$) \mathrm{kg}$, respectively. Although weight gain from weaning to first insemination included also a postpubertal period, it was probably the most suitable estimate of prepubertal growth in the present data set.

Conflicting results in the literature might also be due to different ranges of weight gains in the study materials, because the relationship with milk production has been reported to be curvilinear (Sejrsen et al., 2000). In a meta-analysis of 8 studies on Holstein heifers, Zanton and Heinrichs (2005) concluded that there was a quadratic relationship between average daily weight gain and subsequent first-lactation milk production. Production increased as prepubertal gains increased up to $799 \mathrm{~g} / \mathrm{d}$, whereas further increases were associated with lowered milk production. These results are hence consistent with the findings of Pirlo et al. (1997) that Italian Friesian heifers tolerated an average daily gain of approximately $800 \mathrm{~g}$ from 100 to $300 \mathrm{~kg}$ of BW without any detrimental effect on future milk production. The negative effects of high prepubertal weight gain on mammary development have been reported to start at different levels depending on breed; start at lower daily gains in Jerseys and Danish Reds than in Danish Friesians, resembling Holsteins, was reported by Sejrsen et al. (2000). In the present material consisting of approximately half Holstein and half Swedish Reds, the median growth rate from weaning 
to 6 to 9 mo was 726 (IQR $=619$ to 824 ; minimummaximum $=90$ to $1,253 \mathrm{~g} / \mathrm{d}$ ), whereas the corresponding rate from 6 to 9 mo until first service was 625 (IQR = 539 to 727 ; minimum-maximum $=241$ to $1,254 \mathrm{~g} / \mathrm{d}$ ). Weight gains exceeding $738 \mathrm{~g} / \mathrm{d}$ were the ones associated with the highest production levels. We found no interaction between daily weight gain and breed.

Most reports on negative effects of high prepubertal growth rates on production are based on results from experimental studies on a limited number of animals. Results achieved under experimental conditions might not always be applicable to field conditions, and observational studies might improve our understanding. Mäntysaari et al. (2002), using a field material of 4,058 (mostly Ayrshire) heifers, indeed reported a positive correlation between growth rate before breeding and subsequent first-lactation milk production. However, their study period also included time preweaning; their analysis did not allow adjustment for the herd effect and hence different feed levels, and only $7.6 \%$ of the Ayrshire heifers in their material grew faster than 800 $\mathrm{g} / \mathrm{d}$ before breeding. Our material was also from commercial herds but included animals with somewhat higher average prepubertal growth rates. Prepubertal weight gains were estimated based on growth from weaning, which is more comparable to the start of allometric mammary development. Furthermore, in the analyses, herd was adjusted for by incorporating a random intercept and random slope effect of herd. Our results thus indicate that high prepubertal weight gains are compatible with high first-lactation milk production under practical Swedish conditions.

To our knowledge, the present study is the first to report a significant association between calfhood morbidity and first-lactation milk production. Previous studies have included far less animals and have hence provided lower statistical power. In the study by Warnick et al. (1995), calculations revealed a power of $\geq 0.70$ to detect a reduction of $500 \mathrm{~kg}$ in $305-\mathrm{d}$ milk yield using 728 animals from 25 commercial herds. Diagnoses were made by farmers. The present study, including over 2,000 animals from 107 commercial dairy farms and with farmer diagnoses supplemented with veterinary examinations every second month, detected a reduction of $344 \mathrm{~kg}$, corresponding to losses of approximately 100 euros, per cow. Fourichon et al. (2001), adopting a partial budgeting model and calculating economic losses due to 21 health and reproduction disorders compared with a low-incidence situation, reported that calf diseases contributed to $10 \%$ of the overall losses due to health disorders in dairy farms in the Loire Valley, France. Calculations did not consider long-term effects of calf disorders and no effects on subsequent milk production. Given the effect on subsequent milk production found in the present study, calf morbidity probably accounts for an even higher proportion of health-related losses than the $10 \%$ reported by Fourichon et al. (2001). Economic arguments are important to persuade dairy farmers to allocate more of their resources to calf and young stock management.

Brown et al. (2005) found that calves on higher feeding levels from 2 to $14 \mathrm{wk}$ of age had increased udder parenchymal mass and parenchymal DNA and RNA in mammary glands compared with calves on low-intensity feeding. One explanation for the association between calf morbidity and subsequent milk production found in the present study might therefore be poor feed intake, feed conversion, or both, in diseased calves. Because most cases of diarrhea were mild and diseased calves soon recovered, it seems unlikely that the diarrhea per se caused such effects. Occurrence of diarrhea is, however, strongly associated with respiratory disease, which is known to generally have longer convalescence and more profound effects on growth rate (Lundborg et al., 2003). Svensson et al. (2003), based on the full data set of 0- to 90-d calf morbidity from the present study (3,081 animals from 122 herds), found that 96\% of the calves that had diarrhea before $90 \mathrm{~d}$ of age later developed respiratory disease. The link between diarrhea and respiratory disease might be related to immunosuppression by gastrointestinal infections or to management factors (e.g., poor colostral immunity) predisposing for both diarrhea and respiratory disease in these animals. In the final model of ECM305, we included both diarrhea status and daily growth rate. However, in a preliminary analysis of the present material without daily weight gain in the model (Svensson and Hultgren, 2006), an association between occurrence of respiratory disease and milk production was instead demonstrated. The lack of a significant association between severe diarrhea and milk production is not surprising, because severe cases were rare. Although nonsignificant, it is, however, difficult to explain the negative estimate.

No significant associations between milk yield and housing during the rearing period were found in the multivariable analyses. However, in the univariable analyses, heifers housed in single pens preweaning and in group pens with slatted floors thereafter had lower production than those kept first in single pens and then in litter pens. This is in agreement with experimental findings by Mogensen et al. (1999) that access to bedding during rearing tended to increase milk production $84 \mathrm{~d}$ postpartum compared with housing on a fully slatted floor.

We found that housing in cubicle systems after calving was associated with a reduced 305-d production compared with short stalls. In cubicle systems, primipa- 
rous cows sometimes have to compete for roughage with older and generally higher-ranked cows, which can limit their feed intake.

Large increases in concentrate fed around calving (2 mo precalving to maximum level postcalving) were associated with high milk production. Most animals (73\%) received increasing amount of concentrates starting $\geq 3$ wk before calving. The effects of an adaptation to lactation feeding ration starting $3 \mathrm{wk}$ before calving was evaluated in multiparous cows by Olsson et al. (1998), who found little effect on subsequent milk production. However, it resulted in significantly higher yields in the first month postpartum. The effects of a more prolonged period with high feeding intensity precalving were studied in heifers by Mäntysaari et al. (1999). In addition to grass silage, heifers on highintensity feeding were given 1.75 to $2.25 \mathrm{~kg}$ of barley daily, whereas low-intensity heifers were given 0.5 to $1.0 \mathrm{~kg}$. The authors reported that a high feeding intensity during the last trimester was associated with high milk yield but found no effect of feeding in early gestation.

The majority of mastitis cases are seen early in lactation (Svensson et al., 2006b). A SCC at first-test milking exceeding 1 million per milliliter indicates clinical mastitis. In the present study, such counts and hence most likely clinical mastitis, were associated with reduced milk production at the first test day, which is in accordance with previous findings by Rajala-Schultz et al. (1999). Reductions in milk yield have also been described as a result of a SCC of 600,000 cells $/ \mathrm{mL}$ or less (Hortet et al., 1999).

\section{CONCLUSIONS}

The present study confirms previous findings that an increased age at calving is associated with a higher milk production during first lactation. The results provide further evidence that a high prepubertal weight gain can be compatible with high milk production and that body fatness at first insemination is associated with a reduced first-lactation production. Furthermore, they indicate that there might be benefits from a production perspective of accustoming heifers to large amounts of concentrates around calving. The study suggests that calfhood diarrhea is associated with lowered first-lactation milk production.

\section{ACKNOWLEDGMENTS}

The study was financially supported by the Swedish Farmers' Foundation for Agricultural Research, the Swedish Dairy Association, and the Swedish University of Agricultural Sciences (SLU). We thank the partici- pating farmers for their interest and support. Lotta Andersson, Karin Lundborg, and Jonica Östlund (SLU) and staff from Skara Semin livestock cooperative are acknowledged for their help in data collection. We are grateful to Gunilla Jacobsson (SLU) and Ulf Rundström (Swedish Dairy Association) for help in data processing and to Sven-Ove Olsson (Swedish Dairy Association) and Ulf Emanuelson (formerly Swedish Dairy Association, presently SLU) for help in initiating the project. Mats Pehrsson (Swedish Dairy Association) is acknowledged for his contribution in planning the study and evaluating its results.

\section{REFERENCES}

Britney, J. B., S. W. Martin, J. B. Stone, and R. A. Curtis. 1984. Analysis of early calfhood health status and subsequent dairy herd survivorship and productivity. Prev. Vet. Med. 3:45-52.

Brown, E. G., M. J. Vandehaar, K. M. Daniels, J. S. Liesman, L. T. Chapin, J. W. Forrest, R. M. Akers, R. E. Pearson, and M. S. Weber Nielsen. 2005. Effect of increasing energy and protein intake on mammary development in heifer calves. J. Dairy Sci. 88:595-603.

Carson, A. F., L. E. R. Dawson, M. A. McCoy, D. J. Kilpatrick, and F. J. Gordon. 2002. Effects of rearing regime on body size, reproductive performance and milk production during the first lactation in high genetic merit dairy herd replacements. Anim. Sci. 74:553-565.

Cobo-Abreu, R., S. W. Martin, R. A. Willoughby, and J. B. Stone. 1979. The association between disease, production and culling in a university dairy herd. Can. Vet. J. 20:191-195.

Danell, B. 1982. Studies on lactation yield and individual test-day yields of Swedish dairy cows. 1. Environmental influence and development of adjustment factors. Acta Agric. Scand. 32:65-81.

Dohoo, I., W. Martin, and H. Stryhn. 2003. Veterinary Epidemiologic Research. AVC Inc., Charlottetown, Prince Edward Island, Canada.

Edmonson, A. J., I. J. Lean, L. D. Weaver, T. Farver, and G. Webster. 1989. A body condition scoring chart for Holstein dairy cows. J. Dairy Sci. 72:68-78.

Foldager, J., and K. Sejrsen. 1991. Rearing intensity in dairy heifers and the effect on subsequent milk production. Report 693. Natl. Inst. Anim. Sci., Foulum, Denmark.

Fourichon, C., H. Seeger, F. Beaudeau, and N. Bareille. 2001. Economic losses consecutive to health disorders in dairy farms in Pays de la Loire France. Proc. 52nd Annu. Meet. Eur. Assoc. Anim. Prod., Budapest, Hungary. Wageningen Pers, Wageningen, the Netherlands.

Gardner, R. W., L. W. Smith, and R. L. Park. 1988. Feeding and management of dairy heifers for optimal lifetime productivity. J. Dairy Sci. 71:996-999.

Hessle, A., E. Nadeau, and C. Svensson. 2004. Feeding dairy calves and replacement heifers in south-western Sweden - A survey. Acta Agric. Scand. 54:94-102.

Hoffman, P. C., N. M. Brehm, S. G. Price, and A. Prill-Adams. 1996. Effect of accelerated postpubertal growth and early calving on lactation performance of primiparous Holstein heifers. J. Dairy Sci. 79:2024-2031.

Hortet, P., F. Beaudeadu, H. Seegers, and C. Fourichon. 1999. Reduction in milk yield associated with somatic cell counts up to 600,000 cells/mL in French Holstein cows without clinical mastitis. Livest. Prod. Sci. 61:33-42.

Keown, J. F., and R. W. Everett. 1986. Effect of days carried calf, days dry and weight of first calf heifers on yield. J. Dairy Sci. 69:1891-1896.

Lin, C. Y., A. J. McAlliater, T. R. Batra, and A. J. Lee. 1988. Effects of early and late breeding of heifers on multiple lactation performance of dairy cows. J. Dairy Sci. 71:2735-2743. 
Lundborg, G. K., P. A. Oltenacu, D. O. Maizon, E. C. Svensson, and P. G. A. Liberg. 2003. Dam-related effects on heart girth at birth, morbidity and growth rate from birth to 90 days of age in Swedish dairy calves. Prev. Vet. Med. 60:175-190.

Mäntysaari, P. E., K. L. Ingvartsen, and V. Toivonen. 1999. Feeding intensity of pregnant heifer. Effect of feeding intensity during gestation on performance and plasma parameters of primiparous Ayrshire cows. Livest. Prod. Sci. 62:29-41.

Mäntysaari, P., M. Ojala, and A. E. Mäntysaari. 2002. Measures of before and after breeding daily gains of dairy replacement heifers and their relationship with first lactation milk production traits. Livest. Prod. Sci. 75:313-322.

Mogensen, L., J. T. Sørensen, J. Hindhede, L. H. Nielsen, and A. R. Kristensen. 1999. Effect of space allowance and access to bedding in slatted-floor housing systems during second year rearing on subsequent milk production of primiparous dairy cows. Acta Agric. Scand. Sect. A. Anim. Sci. 49:49-56.

Moore, R. K., B. W. Kennedy, L. R. Schaffer, and J. E. Moxley. 1991. Relationships between age and body weight at calving and production in first lactation Ayrshires and Holsteins. J. Dairy Sci. 74:269-278.

Nilsforooshan, M. A., and M. A. Edriss. 2004. Effect of age at first calving on some productive and longevity traits in Iranian Holsteins of the Isfahan Province. J. Dairy Sci. 87:2130-2135.

Olsson, G., M. Emanuelson, and H. Wiktorsson. 1998. Effects of different nutritional levels prepartum on the subsequent performance of dairy cows. Livest. Prod. Sci. 53:279-290.

Pirlo, G., M. Capelletti, and G. Marchetto. 1997. Effect of energy and protein allowances in the diets of prepubertal heifers on growth and milk production. J. Dairy Sci. 80:730-739.

Rajala-Schultz, P. J., Y. T. Grøhn, C. E. McCulloch, and C. L. Guard. 1999. Effects of clinical mastitis on milk yield in dairy cows. J. Dairy Sci. 82:1213-1220.

Sejrsen, K., L. T. Huber, H. A. Tucker, and R. M. Akers. 1982. Influence of nutrition on mammary development in pre- and postpubertal heifers. J. Dairy Sci. 65:793-800.

Sejrsen, K., S. Purup, M. Vestergaard, and J. Foldager. 2000. High body weight gain and reduced bovine mammary growth: Physiological basis and implications for milk yield potential. Domest. Anim. Endocrinol. 19:93-104.
Silva, L. F. P., M. J. Vandehaar, B. K. Whitlock, R. P. Radcliff, and H. A. Tucker. 2002. Short communication: Relationship between body growth and mammary development in dairy heifers. J. Dairy Sci. 85:2600-2602.

Svensson, C., and J. Hultgren. 2006. The effect of calf rearing factors on first lactation milk production. Proc. 24th World Buiatrics Congr., Nice, France. CD-ROM OS37-1.

Svensson, C., J. Hultgren, and P. A. Oltenacu. 2006a. Morbidity in 3-7-month-old dairy calves in south-western Sweden and risk factors for diarrhea and respiratory disease. Prev. Vet. Med. 74:162-179.

Svensson, C., K. Lundborg, U. Emanuelson, and S.-O. Olsson. 2003. Morbidity in Swedish dairy calves from birth to 90 days of age and individual calf-level risk factors for infectious diseases. Prev. Vet. Med. 58:179-197.

Svensson, C., A.-K. Nyman, K. Persson Waller, and U. Emanuelson. 2006b. Effects of housing, management, and health of dairy heifers on first-lactation udder health in southwest Sweden. J. Dairy Sci. 89:1990-1999.

Tozer, P. R., and A. J. Heinrichs. 2000. What affects the costs of raising replacement dairy heifers: A multiple-component analysis. J. Dairy Sci. 84:1836-1844.

van der Fels-Klerx, H. J., H. W. Saatkamp, J. Verhoff, and A. A. Dijkhuizen. 2002. Effects of respiratory disease on the productivity of dairy heifers quantified by experts. Livest. Prod. Sci. 75:157-166.

Waldo, D. R., A. V. Capuco, and C. E. Rexroad Jr. 1989. Replacement heifer growth rate affects milk producing ability. Feedstuffs 61:15-17.

Warnick, L. D., H. N. Erb, and M. E. White. 1994. The association of calfhood morbidity with first-lactation calving age and dystocia in New York Holstein herds. Kenya Vet. 18:177-179.

Warnick, L. D., H. N. Erb, and M. E. White. 1995. Lack of association between calf morbidity and subsequent first lactation milk production in 25 New York Holstein herds. J. Dairy Sci. 78:28192830

Zanton, G. I., and A. J. Heinrichs. 2005. Meta-analysis to assess effect of prepubertal average daily gain of Holstein heifers on firstlactation production. J. Dairy Sci. 88:3860-3867. 